https://nv.nltu.edu.ua

https://doi.org/10.15421/40290218

$@ \bowtie$ Correspondence author

Article received 06.03.2019 p.

Article accepted 28.03.2019 p.

O. Ya. Kravets

УДК 528.7

olenakravets9@gmail.com

Р. М. Рудий', О. Я. Кравець 2

${ }^{I}$ Уманський національний університет садівництва, м. Умань, Украйна

${ }^{2}$ Івано-Франківський національний технічний університет нафти і газу, м. Івано-Франківськ, Украйна

\title{
РЕЛЬЕФ СТАРТОВИХ ЗОН ВИНИКНЕННЯ СНІГОВИХ ЛАВИН НА ЧОРНОГІРСЬКОМУ ХРЕБТІ УКРАЇНСЬКИХ КАРПАТ
}

\begin{abstract}
Досліджено проблему такого небезпечного стихійного явища, як лавини. Виконано аналіз основних чинників лавиноутворення, а саме морфометричних, метеорологічних та антропогенних. Запропоновано використання геоінформаційних технологій для моніторингу та дослідження потенційно лавинонебезпечних територій, а також для визначення локалізації стартових зон лавин та прогнозування напряму їх руху. Створено цифрову модель рельєфу частини Чорногірського хребта. Виконано візуалізацію стартових зон виникнення снігових лавин двох типів - лійкоподібних, або лоткових та площинних. Створено також тривимірну модель рельєфу, яка візуалізує рельєф, дає його наочне об'єктивне зображення. На ній добре видно основні форми рельєфу, напрямки хребтів, долин, а також місця зародження лоткових і площинних лавин. Порівняно 3 картою, інформативність зображення рельєфу значно вища. Використання такої 3D-моделі рельєфу дає змогу ще наочніше побачити місця можливого виникнення лавин і спрогнозувати напрям їх руху. Проведені дослідження дають змогу виконувати візуалізацію, наочне представлення лавинонебезпечних ділянок та місць можливого зародження лавин, створювати моделі розвитку лавинних процесів залежно від метеорологічних, ботанічних і морфометричних факторів. Результати досліджень $є$ перспективними для туристичної та рекреаційної галузей, оскільки можуть бути використані у проектуванні туристичних маршрутів, будівництві об'єктів рекреації та для прогнозування виникнення снігових лавин.
\end{abstract}

Ключові слова: геоінформаційні технології; цифрова модель рельєфу; лавинні осередки; візуалізація; рекреація.

Вступ. Відомо, що Українські Карпати належать до гірських районів, в яких упродовж віків люди ведуть господарські роботи i, окрім цього, зазначена територія $\epsilon$ привабливою 3 рекреаційної точки зору. Однак однією з істотних небезпек на території Українських Карпат $є$ снігові лавини, які можуть бути досить руйнівними та навіть призводити до людських жертв. На цій території виявлено близько чотирьохсот лавинних джерел (Kolotukha, 2008; Plai \& Pozhyzhevska, 2019; Tykhanovych \& Bilaniuk, 2015). Оскільки снігові лавини $є$ не випадковим явищем, а постійним елементом гірського ландшафту, то вони істотно залежать від елементів цього ландшафту, наприклад, від рельєфу, рослинності, грунтів і т.ін.

На території Івано-Франківської обл. найвища сніголавинна небезпека $\epsilon$ на схилах хребта Чорногора (Grishchenko, 1985; Laviny, 2019), який тягнеться з північного заходу від гори Петрос в Закарпатській обл. на південний схід до гори Піп Іван в Івано-Франківській обл. У дослідженнях розроблено методику розпізнавання та візуалізації схилів 3 певною експозицією, які можуть бути лавинонебезпечними за певних метеорологічних умов.

Для можливості кількісного прогнозування тих чи інших екологічних процесів потрібно виділити основні фактори, що ініціюють їх виникнення. Серед природ- них факторів, дія яких активізує такі стихійні явища, завжди можна виділити провідні (Rudyi \& Husar, 2011; Rudyi, 2018). Так, першопричиною снігових зсувів і лавин $є$ зосередження надмірних запасів снігу на крутих схилах. Певний вплив на активізацію згаданих процесів мають й інші фактори, зокрема характер рельєфу, атмосферні опади, температура, сонячна активність, грунтовий покрив, структура рослинного покриву та ін. Антропогенний вплив на екосистему здійснюється через господарську діяльність в населених пунктах, діяльність землекористувачів, лісогосподарську діяльність, рекреаційну інфраструктуру. Також вагому роль у виникненні та поширенні стихійних процесів відіграють глобальні зміни клімату та зростання техногенного впливу на навколишнє середовище, що проявляються у масштабах всієї біосфери.

Отже, снігові лавини потребують досконального вивчення особливо в гірських районах, що мають рекреаційний потенціал.

Рельєф є одним із основних факторів, що спричиняє виникнення лавин, а снігові лавини, своєю чергою, створюють характерні форми рельєфу (McClung \& Schaerer, 1993; Rudyi \& Husar, 2012). Серед ознак виникнення снігових лавин, що пов'язані 3 рельєфом, можна назвати схили південної та південно-західної експозицій. Якщо на старому снігу на вказаних схилах со-

\section{Інформація про авторів:}

Рудий Роман Михайлович, д-р техн. наук, професор, кафедра геодезії, картографії та кадастру. Email: pavlinarepeta@ukr.net Кравець Олена Ярославівна, канд. техн. наук, доцент, кафедра геодезії та землеустрою. Email: olenakravets9@gmail.com Цитування за ДСтУ: Рудий Р. М., Кравець О. Я. Рельєф стартових зон виникнення снігових лавин на Чорногірському хребті Українських Карпат. Науковий вісник НЛтУ України. 2019, т. 29, № 2. С. 91-93.

Citation APA: Rudyi, R. M., \& Kravets, O. Ya. (2019). The starting zone relief of the emergence of the snow avalanches in Chornohora ridge of the Ukrainian Carpathians. Scientific Bulletin of UNFU, 29(2), 91-93. https://doi.org/10.15421/40290218 
нячного дня утвориться льодова шкірка, то свіжий сніг, який випаде у великій кількості вночі, сповзаючи по схилу і захоплюючи з собою старий сніг, може спричинити лавину. Іншою відомою причиною лавин $\epsilon$ снігові "козирки" (іноді в літературі їх називають карнизи), що утворюються завдяки вітру в певному напрямку. Значна асиметрія сходження лавин пов'язана 3 геоморфологічними особливостями схилів, їх відповідною експозицією та кліматичними особливостями району. Південно-західні та західні вітри під час хуртовин призводять до збільшення випадання снігу на північно-східних та східних схилах. При цьому з гребеня хребта теж зноситься значна кількість снігу на східний схил. Обрив "козирка" теж може спричинити снігову лавину.

Актуальність дослідження. Використання геоінформаційних технологій дає змогу не тільки розв'язувати вказані задачі класифікації та візуалізації схилів i, що найголовніше, не завжди потребує відповідного математичного апарату. Отже, моніторинг та дослідження потенційно лавинонебезпечних територій $є$ актуальним завданням, для вирішення якого передусім варто використати засоби геоінформаційного моделювання.

Мета роботи - проаналізувати найбільш лавинонебезпечні ділянки Чорногірського хребта та 3 допомогою програмних комплексів візуалізувати місця зародження лавин, тобто їхні стартові зони.

Матеріали та методика дослідження. Як відомо (Rudyi \& Husar, 2011, 2012), шлях сходження снігової лавини складається з трьох основних етапів, або морфологічних одиниць: стартової зони, треку та снігозбірної зони. Зміна конфігурації зазначених трьох зон визначає тип та частоту лавин у конкретному місці. Тому, вивчаючи рельєф місцевості як основний фактор лавиноутворення, потрібно особливу увагу приділити дослідженню рельєфу стартової зони.

Виготовлені близько тридцяти років тому та осучаснені (Laviny, 2019) карти місць можливого виникнення снігових лавин $є$ частково застарілими, однак нанесені місця стартових зон дають змогу їх візуалізувати та отримати відповідні кількісні параметри (рис. 1). Запропоновані сучасні технічні та технологічні засоби дають змогу зробити відповідні карти та схеми набагато точнішими. Вони можуть змінюватись в реальному масштабі часу залежно від напрямку вітру та експозиції.

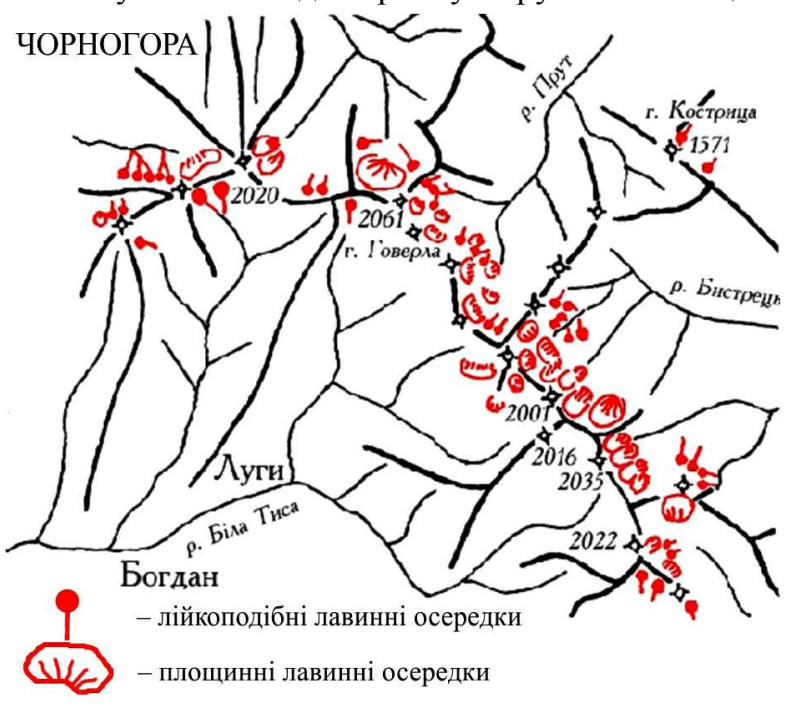

Рис. 1. Стартові зони виникнення снігових лавин (Laviny, 2019)
Для розв'язку цих задач використовують дані дистанційного зондування Землі, що утворює інформаційну основу не тільки для дослідження, спостереження, контролю, оцінки та прогнозу змін навколишнього природного середовища, а й екологічної оцінки територій та відповідної класифікації земель.

У нашому випадку використано програмний комплекс Surfer, який дає змогу візуалізувати лавинонебезпечні ділянки досліджуваної місцевості. 3 його допомогою було створено ЦМР частини Чорногірського хребта (рис. 2-4). На рис. 2 наведено цифрову модель рельєфу, на якій позначено розміщення стартових зон виникнення снігових лавин двох типів - лійкоподібних, або лоткових та площинних. На рис. 3 та 4 наведено стартові зони на 3D-моделі рельєфу, що дає змогу ще наочніше побачити місця можливого зародження лавин та спрогнозувати напрям їх руху.

Результати дослідження. Зауважимо, що коли в інших високогірних частинах Українських Карпат переважають лоткові лавини, які сходять переважно ущелинами, то у верхів'ях Чорногори однаковою мірою зароджуються лавини лоткового i площинного типу (Grishchenko, 1985; Laviny, 2019). Подальший їхній вигляд визначається рельєфом (чи це улоговина, чи плоский схил). Наприклад, як видно з рис. 2, на північних та північно-східних схилах г. Говерла $€$ як лійкоподібні (лоткові), так і площинні лавинні осередки. Те ж саме можна сказати і про південний, західний та північно-західний схили г. Петрос.

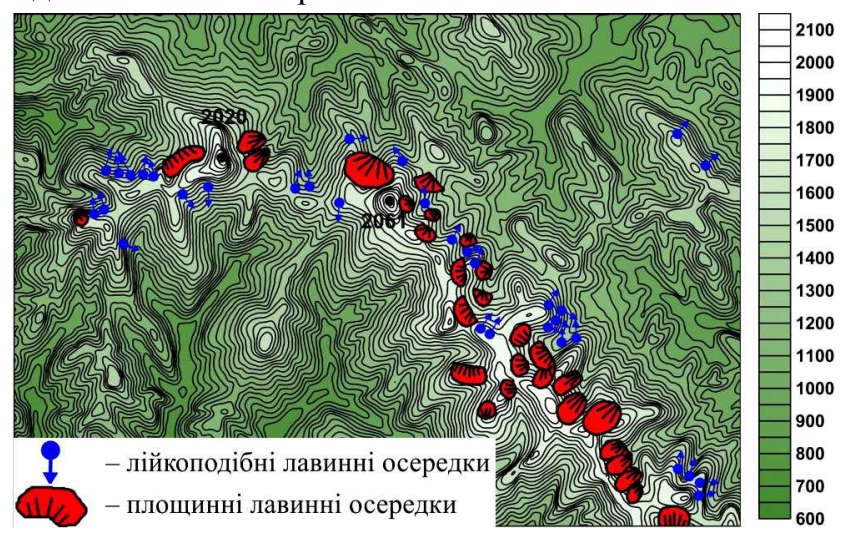

Рис. 2. Цифрова модель рельєфу частини Чорногірського хребта

Варто також зазначити, що зароджені у вказаних місцях лавини можуть бути переважно тоді, коли на їх подальшому шляху не буде лісу твердих порід, або лісу взагалі. Зокрема, південні, західні та північно-західні схили г. Петрос практично позбавлені лісової рослинності. I саме в цих місцях існують лійкоподібні (лоткові) та площинні лавинні осередки. Аналогічна ситуація $\epsilon$ також на північних та північно-східних схилах г. Говерла, а саме - відсутність лісової рослинності та наявність лавинних осередків двох вказаних типів снігових лавин.

У процесі досліджень для візуалізації стартових зон снігових лавин було створено тривимірну модель рельєфу, яка візуалізує рельєф, покращує наочне об'єктивне його зображення. На рис. 3 наведено 3D-модель рельєфу частини Чорногірського хребта 3 візуалізованими лійкоподібними (лотковими) та площинними лавинними осередками. На ній добре видно основні форми рельєфу, напрямки хребтів, долин. Порівняно 3 
топографічною картою чи схемою (Laviny, 2019), інформативність зображення рельєфу значно вища.

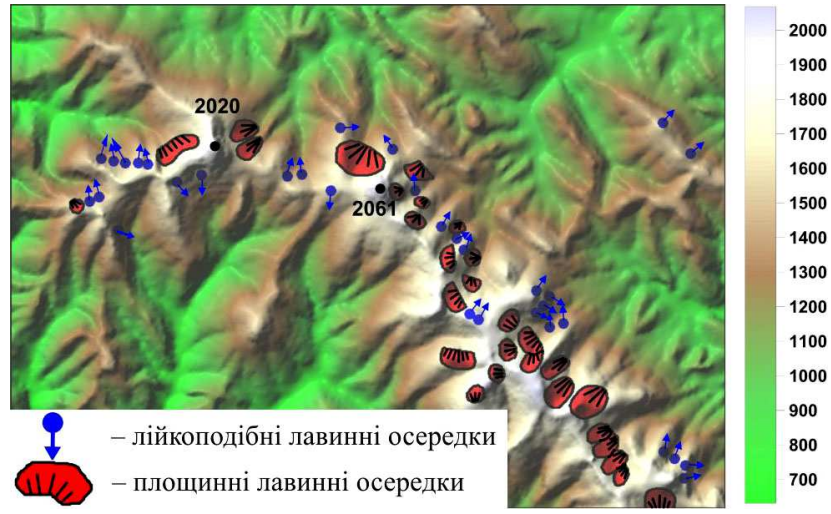

Рис. 3. 3D-модель рельєфу частини Чорногірського хребта

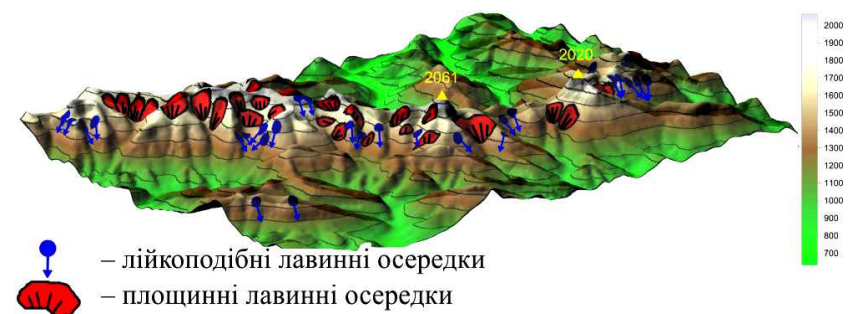

Рис. 4. Візуалізація лавинних осередків на північно-східних схилах Чорногірського хребта

На рис. 4 наведено зображення північно-східних схилів Чорногірського хребта 3 вказаними місцями можливого виникнення лоткових і площинних лавин.

Висновки. Виконані дослідження дають змогу:

1) виконувати візуалізацію, наочне представлення лавинонебезпечних ділянок та місць можливого зародження лавин;

2) створювати моделі розвитку лавинних процесів, залежно від метеорологічних, ботанічних і морфометричних факторів;
3) вдосконалити прогнозування виникнення снігових лавин.

Результати досліджень $є$ перспективними для туристичної та рекреаційної галузей, оскільки можуть бути використані у проектуванні туристичних маршрутів та будівництві об'єктів рекреації.

\section{Перелік використаних джерел}

Grishchenko, V. F. (1985). The forecast of avalanches of snowstorm and fresh snow in the Chernogorsky massif of the Ukrainian Carpathians. Tr. UkrNII Goskomgidrometa, 201, 108-115. [In Russian].

Kolotukha, O. V. (2008). Avalanche danger for tourists in Ukrainian mountains. Kyiv: Federatsiia sportyvnoho turyzmu Ukrainy. [In Ukrainian].

Laviny. (2019). Samye masshtabnye laviny $v$ istorii. Retrieved from: https://4sport.ua/articles? id=27231. [In Russian].

McClung, D. M., \& Schaerer, P. A. (1993). The Avalanche Handbo$o k$. The Mountaineers, Seattle, Wash.

Plai \& Pozhyzhevska. (2019). Tekhnichni zvity sniholavynnykh stantsii Plai i Pozhyzhevska za zymovyi period 2008-2012 rr. [In Ukrainian].

Rudyi, R. M. (2018). Influence of the relief of the Ukrainian Carpathians on the occurrence of snow avalanches. Tezy dop.: Ekolohiia ta ratsionalne pryrodokorystuvannia. Olviiskyi forum - 2018: Stratehii krain Prychornomorskoho rehionu $v$ heopolitychnomu prostori: Mizhnarodna naukova konferentsia, (pp. 36-38). Mykolaiv (Kobleve), June 7-10. [In Ukrainian].

Rudyi, R. M., \& Husar, K. D. (2011). Morphological characteristics of the snow avalanche path. Heodeziia, kartohrafiia i aerofotoznimannia, 75, 88-92. [In Ukrainian].

Rudyi, R. M., \& Husar, K. D. (2012). Analysis of the path and speed of the snow avalanche climb. Suchasni dosiahnennia heodezychnoi nauky ta vyrobnytstva, 2(24), 170-172. [In Ukrainian].

Tykhanovych, Ye. Ye., \& Bilaniuk, V. I. (2015). Avalanche processes in the Ukrainian Carpathians. Journal of Education, Health and Sport, 5(7), 96-104. [In Ukrainian].

\footnotetext{
${ }^{1}$ Uman National University of Horticulture, Uman, Ukraine ${ }^{2}$ Ivano-Frankivsk National Technical University of Oil and Gas, Ivano-Frankivsk, Ukraine
}

R. M. Rudyi', O. Ya. Kravets ${ }^{2}$

\section{THE STARTING ZONE RELIEF OF THE EMERGENCE OF THE SNOW AVALANCHES IN CHORNOHORA RIDGE OF THE UKRAINIAN CARPATHIANS}

Ukrainian Carpathians is the area which is an extremely attractive for development of tourism and recreation activities. However, one of the significant hazards in this area is avalanches and as result can be devastating damages and even leads to life losses, therefore, the study and forecasting of snow avalanches is very important. The purpose of this research is to analyze the most dangerous pattern of the Chornohora ridge and using designated software product to visualize places with most likely conditions for avalanche appearance and critical snow amount accumulation, i.e. their starting zones. There are three main stages for avalanche path, or morphological units: starting zone, track and snowgatering zone. Change the configuration and conditions in all of those three areas defines the type and possibility of avalanches in the particular area. Therefore, studying of terrain relief is the main factor of layout pattern, we have to pay special attention to the study of the topography (relief) of the starting zone. Maps with places of possible occurrence of snow avalanches were made about 30 years ago and now are basically outdated, but now, making use of the geoinformation technologies allows to modernize and visualize most likely possible starting zones of snow avalanches and to obtain relevant quantitative, mathematically approved parameters. The software package Surfer, which allows you to visualize avalanche pattern of the area of our interest in our case was used. DEM as a part of Chornohora ridge was created, the location of snow avalanches starting zones with high possibility of two types of development - gutter and planar were marked. Also this 3D terrain model allows to spot the possible accumulation of forces and conditions for avalanches occurrence and to predict direction of their movement. This research made it possible to render a visually represent of avalanche dangerous areas and areas of possible origin of avalanches, enable to create the models of avalanche development as a processes depending on meteorological, botanical, and morphometric factors. The results of the study for the tourism and recreational industry, and also to develop and design of different tourist routes, construction of recreation objects and to predict the occurrence of snow avalanches can be used.

Keywords: geoinformation technologies; digital terrain model; avalanche foci; visualization; recreation. 